„Przekłady Literatur Słowiańskich”. T. 10, cz. 2

ISSN 2353-9763 (wersja elektroniczna)

DOI https://doi.org/10.31261/PLS.2020.10.02.09

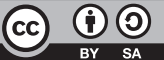

\title{
Ślad Jerzego Pleśniarowicza pozostawiony w przekładach
}

\section{Jerzy Pleśniarowicz’s Trace Left in Translations}

\author{
Marta Buczek \\ iD https://orcid.org/0000-0001-9623-2460 \\ UNIVERSITY OF SILESIA IN KATOWICE \\ marta.buczek@us.edu.pl \\ Data zgłoszenia: 1.03 .2020 r. ～～Data akceptacji: 29.05 .2020 r.
}

\begin{abstract}
This article focuses on the career of Jerzy Pleśniarowicz, the well-known poet of the Józef Czechowicz group and Polish translator of Slavic literatures, as well as dramatist and theatre director. A discussion of the output of this poet and translator is accompanied by an analysis of his Polish translations of Slovak poetry presented in the 2018 volume Wiersze i przekłady wierszy (Poems and Translated Poems). The article considers Pleśniarowicz's translation choices, elucidates his translation strategies, and discusses the contemporary significance of this poetry within the Polish sphere of reception.
\end{abstract}

KEYWORDS | Slovak poetry in Poland, Polish translations of Slovak poetry, reception of translations, Polish reception of Slovak poetry, Jerzy Pleśniarowicz, translator's visibility 
Ślady tłumacza są „,ważnym źródłem wiedzy o rządzących wymianą kulturową prawach i o roli, jaką w niej wyznaczono przekładowi w ogóle, przekładowi konkretnego dzieła zaś w szczególności, oraz tłumaczowi jako działającemu podmiotowi” - podkreśla Magdalena Heydel ${ }^{1}$. Ogromną rolę w pracy nad przekładem odgrywają jednostkowe, twórcze decyzje tłumacza (interpretacja, wybór stylistyki i poetyki), będące równocześnie deklaracją wyznawanych przez niego poglądów na temat przekładu jako fenomenu kulturowego. Ponosi on równocześnie, jak podkreśla Anthony Pym, odpowiedzialność za uruchomione przez przekład procesy społeczne, a jego obecność jest kluczowa ${ }^{2}$ dla tworzenia przestrzeni dialogu, nawiązywania komunikacji między kulturami, informowania o obcym, dążenia do zrozumienia innego ${ }^{3}$. Wyznając ideę dialogu, tłumacz pokonuje dystans między literaturami, umożliwia poznanie, doświadczenie obcego/innego poprzez zanurzenie w historii, kulturze, języku. W zadaniach tłumacza zawiera się nie tyle idea udostępnienia utworów czytelnikom, ile weryfikacja wartości dzieła, szczególne podejście do niego pojmowane w aspekcie dialogu, wprowadzenie go w uniwersum dyskursu, wprawienie go w ruch ${ }^{4}$. Tak zadanie i rola tłumacza pojmowane są w wydanym w 2018 roku tomie pt. Wiersze i przekłady wierszy ${ }^{5}$, przypominającym twórczość poetycką i przede wszystkim wybrane przekłady poezji Jerzego Pleśniarowicza, cenionego w powojennej historii polskich przekładów literatur słowiańskich tłumacza ${ }^{6}$. Zbiór, opracowany i zredagowany przez syna oraz wnuka tłumacza - Krzysztofa i Jana Pleśniarowiczów, odkrywa na nowo „Życiowy projekt” autora, ale również

1 M. Heydel, 2013: Gorliwość ttumacza. Przekład poetycki w twórczości Czesława Miłosza. Kraków, Wydawnictwo Uniwersytetu Jagiellońskiego, s. 60.

2 A. Pym, 1998: Introduction. W: Idem: Method of Translation History. Manchester, St. Jerome Publishing, s. IX.

3 Por. P. Ricoeur, 2008: Radości i udręki tłumaczenia. W: Idem: O tłumaczeniu. T. Swoboda, S. Ulaszek, tłum. E. Balcerzan, wstęp. Gdańsk, Wydawnictwo Uniwersytetu Gdańskiego, s. 33-38; M. Heydel, 2013: Przekład w paradygmacie myśli hermeneutycznej. W: Eadem: Gorliwość tłumacza..., s. 91-95.

4 Por. M. Heydel, 2013: Tradycja, repryza, twórczość. W: Eadem: Gorliwość tłumacza..., s. 105.

5 J. Pleśniarowicz, 2018: Wiersze i przekłady wierszy. K. Pleśniarowicz, J. Pleśniarowicz, red. Kraków, Bricolage Publishing.

6 Tom pt. Wiersze i przekłady wierszy jest pierwszym w serii wydaniem nawiązującym do twórczości przekładowej Jerzego Pleśniarowicza. Warto także dodać, że we wcześniejszej publikacji, z 1993 roku, jej autor, syn poety i tłumacz Krzysztof Pleśniarowicz (por. K. Pleśniarowicz, 1993: Jerzego Pleśniarowicza ślad pozostawiony. K. Pleśniarowicz, wybór i oprac. Kraków, Szkice), rozpatrywał aktywność twórczą Jerzego Pleśniarowicza, w mniejszym stopniu poświęcając uwagę jego aktywności przekładowej. Powstające współcześnie publikacje na temat tego twórcy starają się utrwalić jego „ślad” nie tylko jako autora, lecz przede wszystkim jako tłumacza oraz ambasadora kultur, z których przekładał. 
swoisty „horyzont tłumacza”" , tkwiące w jego twórczości i przekładach sposoby odczuwania, działania, myślenia, zdeterminowane przez zestaw językowych, literackich, kulturowych i historycznych parametrów.

Jerzy Pleśniarowicz (1920-1978) — poeta, reżyser teatralny i radiowy, dramaturg, animator kultury, autor tomów poetyckich ${ }^{8}$, redaktor antologii poezji ${ }^{9}$, monografii ${ }^{10}$, współautor i tłumacz antologii przekładów poezji z literatur słowiańskich $^{11}$, również uznany tłumacz literatury, między innymi słowackiej ${ }^{12}$

7 Pojęcie „horyzont tłumacza” przyjmuję za A. Bermanem. Por. A. Berman, 2009: Toward a Translation Criticism: John Donne. F. Massardier-Kenney, ed. Kent State University Press. Za: M. Heydel, 2013: Bermana model krytyki przekładu. W: Eadem: Gorliwość tlumacza..., s. 99.

8 Por. J. Pleśniarowicz, 1939b: Śpiew pierwszy. Warszawa, Wydawnictwo F. Hoesicka; J. Pleśniarowicz, 1939a: Arkusz poetycki nr 20. Warszawa, Wydawnictwo F. Hoesicka; J. Pleśniarowicz, 1942: Droga. Lublin, Wydawnictwo konspiracyjne; J. Pleśniarowicz, 1987: Ballada o ułanach i inne wiersze z lat 1936-1945. Kraków, Wydawnictwo Literackie. Twórczość Jerzego Pleśniarowicza trafiała także do powojennych antologii poezji (por. R. Matuszewski, S. Pollak, wyb., 1962: Poezja polska 1914-1939. Warszawa, Czytelnik; W. Mrozowski, oprac., 1965: Antologia lubelskich poetów dwudziestolecia międzywojennego. Lublin, Wydawnictwo Lubelskie; R. Rosiak, oprac., 1967: Tu jest nasz dom. Antologia wierszy o Lublinie. Lublin, Wydawnictwo Lubelskie; J. Szczawiej, oprac., 1974: Poezja Polski Walczacej. Warszawa, Państwowy Instytut Wydawniczy). Była również przekładana na języki ukraiński, słowacki, serbski. Por. K. Pleśniarowicz, 2018: Nota edytorska. W: Idem: Wiersze i przekłady wierszy..., s. 849.

9 Por. Jerzy Pleśniarowicz, red., 1945: Wybór wierszy poetów lubelskich. Lublin, Związek Zawodowy Literatów Polskich; J. Pleśniarowicz, red., 1974: Wiersze z Rzeszowskiego. R. Matuszewski, przedm. Lublin, Wydawnictwo Lubelskie.

10 Por. J. Pleśniarowicz, 1985: Kartki z dziejów rzeszowskiego teatru. K. Pleśniarowicz, oprac. Rzeszów, Krajowa Agencja Wydawnicza.

11 Por. J. Huszcza, red., 1971: Wiersze białoruskie. Łódź, Wydawnictwo Łódzkie; F. Nieuważny, J. Pleśniarowicz, red., 1978: Antologia poezji ukraińskiej. F. Nieuważny, S. Kozak, wstęp. Warszawa, Ludowa Spółdzielnia Wydawnicza.

12 Zainteresowanie literaturą słowacką zaowocowało wydaniami tłumaczeń w antologiach poezji, m.in. Antologia poezji czeskiej i słowackiej XX w. (Katowice, Wydawnictwo Śląsk, 1972), Drzewo rośnie zielono (J. Waczków, red., Warszawa, Iskry, 1969), publikacjami książkowymi liryki słowackich poetów — Miroslava Válka: Cztery księgi niepokoju (Katowice, Wydawnictwo Śląsk, 1974), Vojtecha Mihálika: Płomień i pocałunek (Kraków, Wydawnictwo Literackie, 1978), przekładami prozy Vincenta Šikuli: Wakacje ze stryjem Rafaelem / Prázdniny so strýcom Rafaelom (Katowice, Wydawnictwo Śląsk, 1976). Rozwijając swoje pasje teatralne, Pleśniarowicz przełożył m.in. dramaty Júliusa Barča-Ivana: Dwaj / Dvaja (1968), Ivana Bukovčana: Serce Luigiego albo egzekucja tępym mieczem / Luigiho srdce alebo oprava tupým mečom (1975), Lubomíra Feldka: Botafogo / Botafogo (1975); Botafogo w butach / Botafogo v čižmách (1980), Osvalda Zahradníka: Solo na zegar z kurantem / Sólo pre bicie hodiny (1973). Więcej o przekładach Jerzego Pleśniarowicza dramatów słowackich w Polsce por. L. Spyrka, 2016a: Dramat słowacki w Polsce. Przekład w dialogu kultur bliskich. Katowice, Wydawnictwo Uniwersytetu Śląskiego, s. 261, 263, 266, 297 i dalsze. 
i czeskiej ${ }^{13}$, wpisuje się tomem Wiersze i przekłady wierszy we współczesny pol222 ski horyzont odbioru, przefiltrowując przez współczesną świadomość odbiorcy sekundarnego poetykę przeszłości. Zaprezentowane tu tłumaczenia poezji ${ }^{14}$ : słowackiej, czeskiej (m.in. utworów Ludvíka Aškenazego, Ivana Diviša, Miroslava Floriana, Miroslava Holuba, Jaroslava Seiferta, Jana Skácela), ukraińskiej (Maksima Tanka), rosyjskiej (Iwana Bunina, Siergieja Jesienina, Michaiła Lermontowa, Aleksandra Prokofiewa, Aleksandra Puszkina), także litewskiej (Justinasa Marcinkievičiusa, Eduardasa Mieželaitisa), estońskiej (Jaana Krossa), gruzińskiej (Michy Kwliwidzego), ormiańskiej (Aszota Grasziego) czy francuskiej (Henriego Barbuse’a, Charles’a Baudelaire’a, Paula Éluarda, Alfreda de Musseta, Arthura Rimbauda, Tristana Tzary czy Paula Verlaine’a), wyznaczają linię łączności między przeszłością, tradycją a współczesnością. Literatura słowacka stanowi w zbiorze znaczącą, po literaturze ukraińskiej, część, zawierającą przekłady ponad 150 utworów 35 poetów słowackich, których zestawienie daje szeroki przekrój przez słowacką poezję XX wieku, odkrywając równocześnie upodobania i zainteresowania poetyckie sterujące strategiami makro- oraz mikrowyborów tłumacza.

Autorskie wiersze Jerzego Pleśniarowicza stanowią ważną część dorobku Drugiej Awangardy z lat 30. XX wieku ${ }^{15}$, a jego działalność przekładowa zyskała międzynarodowe uznanie. Słowacki poeta i tłumacz Lubomír Feldek, którego poezję Jerzy Pleśniarowicz przekładał, oddał hołd tłumaczowi, pisząc: „żadna cecha nie charakteryzuje go lepiej, jak właśnie zdolność pochylenia się nad różnobarwną poezją różnych poetów, różnych narodowości, najwięcej jednak poetów słowiańskich, a spośród nich najbardziej polskich, ukraińskich, czeskich i słowackich”16. Feldek, również zasłużony słowacki tłumacz ${ }^{17}$, podkreślał rolę

13 Z literatury czeskiej przełożył m.in. poezję Miroslava Holuba (Model człowieka, Warszawa, PIW, 1969); dramaty Ladislava Smočka (Piknik / Piknik, 1967) i Miloslava Stehlíka (Czapajev / Čapajev, 1972).

14 Podstawę antologii stanowią przekłady publikowane wcześniej w czasopismach i tomach wierszy oraz $\mathrm{w}$ antologiach, $\mathrm{z}$ uwzględnieniem późniejszych autorskich poprawek. Do antologii dołączono także utwory z rękopisów i maszynopisów tłumacza, przechowywanych w rodzinnym archiwum. Por. K. Pleśniarowicz, 2018: Nota edytorska. W: J. Pleśniarowicz: Wiersze i przekłady wierszy..., s. 851.

15 Jerzy Pleśniarowicz jako poeta debiutował w 1937 roku Ballada o ułanach na łamach warszawskiego tygodnika „Pion”. Publikował swoją poezję w licznych czasopismach: łuckim „Wołyniu”, chełmskiej „Kamenie”, warszawskim „Apelu” (dodatku do „Kuriera Porannego”), poznańskiej „Kulturze”, łódzkich „Wymiarach” i in. Por. K. Pleśniarowicz: Nota edytorska..., s. 849-850.

16 J. Pleśniarowicz, 2018: Wiersze i przekłady wierszy... (z notki biograficznej na okładce).

17 Feldek tłumaczył m.in. poezję rosyjską (Alexandra Bloka, Władimira Majakovskiego, Sergieja Jesenina, Aleksandra Puszkina), polską (Juliana Tuwima), francuską (Artura Rimbauda, Guillaume’a Apollinaire’a), angielską (Williama Shakespeare’a), rozwi- 
aktu translacji polskiego tłumacza, dzięki któremu odkrył twórczość wybitnego ukraińskiego poety Bohdana Ihora Antonycza. „Słowiański dzban z Zielonej Ewangelii Antonycza stoi też na stole, na którym powstawało dzieło Jerzego Pleśniarowicza" - wspominal $^{18}$. W takim ujęciu tłumacz stawał się twórcą, który poprzez odpowiedni wybór tekstów oraz strategie translacji powoduje, że utwór, cytując Ezrę Pounda, „nie trafia do muzeum, ale zamienia się w nową wartość" ${ }^{19}$. Wartość przekładów polskiego poety i tłumacza polegała na wprowadzeniu w horyzont odbioru nowych możliwości znaczeniotwórczych, na wzbogacaniu rodzimego języka i literatury przez wykorzystanie rozwiązań $\mathrm{z}$ innych/obcych literatur oraz, co potwierdzają słowa słowackiego poety, na oddziaływaniu i wywieraniu wpływu na twórczość innych pisarzy.

Jerzy Pleśniarowicz jako tłumacz zadebiutował w 1937 roku w tygodniku „Wołyń”, w którym ukazał się przekład utworu Kołysanka wspomnianego Bohdana Ihora Antonycza ${ }^{20}$. Swoje tłumaczenia zamieszczał w licznych czasopismach: „Kamena”, „Akcent”, „Kultura i Życie” — z Lublina, „Dziennik Polski”, „Gazeta Krakowska”, „Pismo Literacko-Artystyczne”, „Życie Literackie” - z Krakowa, „Kultura”, „Poezja”, „Literatura na Świecie”, „Tygodnik Kulturalny”, „Współczesność” - z Warszawy, „Nurt” - z Poznania, „Nowiny Rzeszowskie”, „Orka” z Rzeszowa i innych ${ }^{21}$. W ciągu ponad 20 lat, w okresie 1955-1978, zwanym również rzeszowskim ${ }^{22}$, opublikował w czasopismach, 14 tomach poezji

jając w słowackich kręgach teorię przekładu. Szerzej o działalności przekładowej i teoretycznej L. Feldka por. L. Spyrka, 2016b: Koncepcja przekładu L’ubomíra Feldka w kontekście słowackiej myśli przekładoznawczej. „Przekłady Literatur Słowiańskich”, t. 7, cz. 1, s. 64-77.

18 J. Pleśniarowicz, 2018: Wiersze i przekłady wierszy...

19 E. Pound, 1968: Literary Essays of Ezra Pound. New York, New Directions, s. 200. Cyt. za: M. Heydel, 2013: Tradycja, repryza, twórczość..., s. 106.

20 Por. K. Pleśniarowicz, 2018: Nota edytorska..., s. 849-850.

21 Por. Spuścizna translatorska Jerzego Pleśniarowicza: poezja słowacka. „Kamena” 1985, nr 4 (824); także G. Debkiewicz, A. Wilk, oprac., [online]: Spis zawartości czasopisma „Kamena” w latach 1945-1993. Dostępne w Internecie: http://biblioteka.teatrnn.pl/ dlibra/Content/26063/KAMENA_umcs_ost.pdf [dostęp: 10.12.2019]; K. Pleśniarowicz, 2018: Nota edytorska..., s. 850.

22 Jerzy Pleśniarowicz, związany na stałe ze środowiskiem literackim, kulturalnym i teatralnym w Rzeszowie, w latach 1952-1974 był kierownikiem literackim Teatru Ziemi Rzeszowskiej (od 1957 roku - Teatru im. Wandy Siemaszkowej w Rzeszowie), współpracował z rzeszowską rozgłośnią Polskiego Radia, m.in. jako adaptator i reżyser słuchowisk, emitowanych także na antenie ogólnopolskiej, oraz z Wojewódzkim Domem Kultury, redakcjami „Nowin Rzeszowskich”, „Nowin Tygodnia” i „Widnokręgu”. W latach 1956-1973 wyreżyserował 15 przedstawień, m.in.: Dzikusy Sergieja Michałkowa, Matka Maksyma Gorkiego, Medea Eurypidesa, Pięć wieczorów Aleksandra Wołodina, Gdzie jest Abel, brat twój Juliu Edlisa, Antygona Jeana Anouilha, także z klasyki słowackiej - Dwaj Júliusa Barča-Ivana. Był 
i 10 antologiach blisko 500 przekładów poetyckich, kilkadziesiąt ukazało się po 224 jego śmierci w 1978 roku. Wybory translatorskie Pleśniarowicza wpisywały się w jego zainteresowania jako pisarza i poety, uruchamiał w nich przyjętą przez siebie swoistą perspektywę interpretacyjną. W przypadku literatury słowackiej wybór najczęściej padał na twórczość eksperymentalną, awangardową, nowatorską językowo lub stylistycznie, odsłaniającą ukryte w niej interpretacyjne możliwości. Większość jego tłumaczeń stanowiły utwory poetów z kręgu słowackich nadrealistów, przetłumaczył między innymi wiersze Rudolfa Fabrego, Vladimíra Reisela, Pavla Bunčáka, Júliusa Lenki, Štefana Žárego. Ze współczesnej literatury najczęściej sięgał po poezję twórców z Trnavy, określanych również grupą trnawską (Trnavská skupina), konkretystami czy sensualistami ${ }^{23}$. Z powodzeniem tłumaczył wiersze założyciela grupy L'ubomíra Feldka oraz jej przedstawicieli Jána Ondruša, Jána Stachy i kontynuatorów, między innymi Jána Šimonoviča. Jego translatorskie upodobanie do współczesnej słowackiej poezji oscylowało głównie wokół pisarzy z kręgu generacji Mladej tvorby, debiutujących po 1956 i 1963 roku, zainteresowanych nowymi tematami, motywami (przejętymi z egzystencjalizmu, eksponującymi uniwersalizm przejawów ludzkiej egzystencji) i przede wszystkim eksperymentowaniem z formą artystycznego przekazu. Przekładał między innymi wiersze Jána Buzássego, Vlastimila Kovalč́ka, Vojtecha Kondróta, a także mniej znanych: Tomáša Janovica, Mikuláša Kováča, Mariána Kováčika, oraz autorów dla współczesnej poezji słowackiej najbardziej znaczących, podtrzymujących w latach 50. i 60. XX wieku więzy generacyjne między młodszymi i starszymi poetami: Milana Rúfusa, Miroslava Válka ${ }^{24}$. W słowackiej literaturze przełomu roku 1956 oraz 1963 Rúfus i Válek, a także kilka lat młodsi Feldek, Mihalkovič, Ondruš i Stacho tworzyli

współinicjatorem Rzeszowskich Spotkań Teatralnych (od 1961 roku), wchodził w skład kolegiów redakcyjnych „Kwartalnika Rzeszowskiego” (1967-1968) i miesięcznika „Profile” (Rzeszów, 1969-1972). Był założycielem i prezesem Rzeszowskiego Oddziału Związku Literatów Polskich (1967) oraz autorem antologii pt. Wiersze z Rzeszowskiego (1974). Por. hasło: Jerzy Pleśniarowicz zamieszczone w Wikipedii: https://pl.wikipedia.org/wiki/Jerzy_Ple\%C5\%9Bniarowicz [dostęp: 5.01.2020], a także: http://www.encyklopediateatru.pl/autorzy/3850/jerzy-plesniarowicz [dostęp: 5.01.2020]; A. Bosak, [online]: Rzeszowski teatr wspomina Jerzego Pleśniarowicza. Dostępne w Internecie: https://www.biznesistyl.pl/ludzie/sylwetki/5235_html [dostęp: 5.01.2020].

23 Por. I. Sedlák a kol., 2009: Trnavská skupina a jej vývinové podnety. W: I. Sedlák, L. Č́zy: Dejiny slovenskej literatúry II. Bratislava, Martin, Literárne informačné centrum, Matica slovenská, s. 340-341.

24 L. Feldek o generacji debiutujących po wojnie poetów pisał: „rozhodujúcim kritériom je vývinové hladisko - generáciu tvorí skupina spisovatelov [...], ktorí majú spoločné a jednotné poňatie úloh literatúry a príbuzný spôsob jej uskutočňovania”. M. Hamada, 1966: Vhladaní významu a tvaru. Bratislava, Smena, s. 18. 
generacyjną jedność ${ }^{25}$. W swoich translatorskich wyborach Jerzy Pleśniarowicz starał się odkryć przed odbiorcą sekundarnym wzajemne, wynikające z tej wspólnoty, artystyczne zainteresowania, generacyjne powiązania, sposób tworzenia. Wypełniał sekundarny horyzont odbioru utworami, które inklinowały w kierunku neoawangardowego eksperymentu, nawiązując równocześnie więź $\mathrm{z}$ awangardową poezją okresu międzywojennego (surrealizmem, słowackim nadrealizmem, czeskim poetyzmem, m.in. poezją Nezvala, Biebla), dlatego $\mathrm{w}$ jego zestawieniach przedstawiciele grupy trnawskiej pojawiają się obok słowackich nadrealistów (Fabrego, Reisela, Bunčáka, Lenki). Ze starszej poezji tłumaczył wymagające poetyckiego kunsztu i znajomości artystycznego warsztatu wiersze słowackiego parnasisty Pavla Országha Hviezdoslava, a także przedstawiciela Slovenskej moderny Janka Jesenskiego, wpisującego się w osiągnięcia poezji parnasizmu oraz modernizmu, znanego słowackiego historyka, krytyka i teoretyka literatury Štefana Krčmérego ${ }^{26}$ czy najsłynniejszego słowackiego witalisty Jána Smreka.

Pleśniarowicza jako poetę, ale również tłumacza interesowała przede wszystkim poezja opierająca się na zmysłowym postrzeganiu rzeczywistości, poezja konkretna, wykorzystująca nowoczesne typy obrazowania, poezja fantazyjna i intymna zarazem. W wierszach, które wybierał do tłumaczenia, dominantę znaczeniową stanowiły metaforyczność, asocjacje, zmysłowe nasycenie, często zaskakujące, niekonwencjonalne obrazowanie. Pleśniarowicz, „najmłodszy poeta z kręgu Czechowiczowskiego" ${ }^{27}$, w swojej twórczości odrzucał referencyjną bezpośredniość i opisowość, schematyczną wyobraźnię, potoczne kategorie widzenia świata. Poszukując nowych zasad poznania i nowych sposobów objawiania się tajemnicy ludzkiego istnienia, wykorzystywał metaforę, awangardową poetykę asocjacyjną, bliska była mu zatem poezja grupy konkretystów z Trnavy, dla których potrzeba metaforyczności - według Feldka: „metaforický princíp” ${ }^{28}$ stała się podstawą tworzenia. Awangardowa poetyka asocjacyjna, emocjonalna i imaginatywna siła metafory, jej kognitywne, poznawcze możliwości implikowane w poetyce twórców grupy otwierały nowe perspektywy w doborze strategii przekładu, wymagając od tłumacza poetyckich i warsztatowych zdolności.

25 Por. I. Sedlák a kol., 2009: Vývinová dynamika v „zlatých šest'desiatych“. W: I. Sedlák, L. Čúzy: Dejiny slovenskej literatúry II..., s. 360; http://pdf.truni.sk/e-skripta/sl45a/3b. pdf [dostęp: 2.01.2020].

26 Štefan Krčméry jest autorem dwutomowego dzieła dotyczącego historii słowackiej literatury. Por. Š. Krčméry, 1943: Stopätdesiat rokov slovenskej literatúry. Martin, Matica slovenská.

27 J. Pleśniarowicz, 2018: Wiersze i przekłady wierszy..., s. 9.

28 L. Feldek, 1962: Metaforou ku komplexnosti. „Kultúrny život”, č. 32; http://pdf.truni. sk/e-skripta/sl45a/3b.pdf [dostęp: 2.01.2020]. 
Zainteresowanie tłumacza wzbudził również debiutujący w słowackiej literaturze w latach 60. XX wieku, po okresie kulminacji grupy trnawskiej, Štefan Strážay, który wytworzył szczególny i indywidualny, usytuowany poza grupowymi wystąpieniami styl tworzenia ${ }^{29}$. Czysty opis, lakoniczna oszczędność słowa, sytuacyjny skrót, eliptyczność (przejawiająca się m.in. w eliminacji czasownika kosztem wyeksponowanych rzeczowników i ich określników oraz w swoistej przebudowie składni) - wszystkie te środki artystycznego przekazu konstytuowały liryczny świat przedmiotów (rzeczy), pośród których w przestrzeni "pomiędzy” skrywał się podmiot (człowiek) i jego przeżycia. Pleśniarowicza i Strážaya połączyło podobieństwo poetyki, zbieżny sposób postrzegania, percypowania i konceptualizowania rzeczywistości. Podobnie jak słowacki poeta, wyzwalał on słowa $z$ więzi zdań, tworząc w ten sposób nowe schematy; „używał obficie zdań szczątkowych lub zawieszonych na niedokończonej całostce logicznej”30 ${ }^{30}$ Analogiczną strategię stosował w swoich przekładach, poszukując ekwiwalentów, oddawał specyfikę poetyki, antyintelektualizm poetyckiej wypowiedzi, w której skrywała się głębsza myśl, niedostępna wszystkim odbiorcom. O pokrewnym sposobie tworzenia i przekładu można mówić także w przypadku twórczości Vojtecha Kondróta, również debiutanta lat 60. ubiegłego wieku, którego wiersze operujące werbalnym skrótem, nasycone eksperymentalnym rymem Pleśniarowicz tłumaczył.

Translatorskie wybory Jerzego Pleśniarowicza - tłumacza poezji, również prozy $^{31}$ - ściśle powiązane z jego drogą pisarską i poetycką, nie były proste,

29 Por. I. Hochel, 2007: Poézia. W: I. Hochel, L. Čúzy, Z. Kákošová: Slovenská literatúra po roku 1989. Bratislava, Literárne informačné centrum, s. 41; V. Mikula, 2005: Strážay Štefan. W: V. Mikula, ed.: Slovník slovenských spisovatelov. Bratislava, Kalligram, Ústav slovenskej literatúry SAV, s. 514-515; V. Mikula, 1987: Hladanie systému obraznosti. Bratislava, Smena, s. 109-126; Z. Rédey, 2017: Od „poézie veci” $k$ „poetike vecnosti” (Lyrika Štefana Strážaya). Levoča, Modrý Peter.

30 J. Pleśniarowicz, 2018: Wiersze i przekłady wierszy..., s. 10.

31 W 2019 roku ukazał się drugi tom dotyczący działalności przekładowej Jerzego Pleśniarowicza, tym razem poświęcony przekładom prozy, por. J. Pleśniarowicz, 2019: Przekłady prozy. K. Pleśniarowicz, J. Pleśniarowicz, red. Kraków, Bricolage Publishing. Tłumacza interesowała szczególnie krótka forma opowiadania, nowela czy powiastka, małe formy prozatorskie nabierające cech wielkiej literatury i reprezentujące niejednokrotnie arcydzieła narracji i opisu. „Jakkolwiek utwory te nie przekraczają na ogół kilku stron (niekiedy bywają nawet krótsze), nie należą wcale do form łatwych - podkreślał tłumacz - ponieważ lakoniczność i zawartość »małej formy« stawia przed pisarzem znaczne wymagania. Istota sztuki krótkiego opowiadania polega bowiem - jak powiedział Maksym Gorki - na umiejętności »wyrazistego przedstawiania miejsca akcji, żywości postaci, precyzji i barwności języka«. »Opowiadanie $[\ldots]$ powinno być napisane tak, by czytelnik widział to wszystko, o czym opowiada autor «". J. Pleśniarowicz, 2019: Przekłady prozy..., s. 10-11. Tom zawiera przekłady wspomnianej małej formy prozatorskiej słowackiej pisarki Natašy Tanskiej 
wyłamywały się z oficjalnej polityki przekładowej ${ }^{32}$. W tę natomiast wpisywały się tłumaczenia wierszy Milana Lajčiaka, Fraňa Krála, Andreja Plávki, przedstawicieli socjalistycznego realizmu ${ }^{33}$. Wybór poezji piewców ustroju nie był jednak jednoznaczny, świadczyć o tym mogą przekłady wierszy Vojtecha Michálika, spośród których uznanie tłumacza znalazły te utwory, które wymykają się jednoznacznej interpretacji ${ }^{34}$. Pleśniarowicz sięgał do wierszy poety, w których pobrzmiewa tradycja parnasizmu Pavla Országha Hviezdoslava, symbolizmu Ivana Kraski, międzywojennego neosymbolizmu. Translatorski wybór w tym przypadku koncentrował się na utworach nasyconych niekonwencjonalną obrazowością i symbolami, charakteryzujących się ekspresywnością języka, melodyjnością frazy, wersem sylabotonicznym (Anjeli, 1947; Tŕpky, 1963; Appassionata, 1964). Podobnie jak w przypadku wierszy nadrealistów czy konkretystów, akt translacji wybranej poezji Mihálika wymagał od tłumacza poetyckiego wyczucia i warsztatowego kunsztu. Pleśniarowicz, decydując się na przekład wierszy ze zbiorów nieobciążonych ideologicznym schematyzmem, odkrył wartość poety, który zapamiętany został $\mathrm{w}$ rodzimym horyzoncie odbioru jako przedstawiciel poezji realizmu socjalistycznego. W polskim horyzoncie odbioru, dzięki wyborom i tłumaczeniu Pleśniarowicza, Mihálik jawi się w odmienny sposób, sytuując się w kręgu poetów współczesności.

W translatorskich wyborach Pleśniarowicza uzewnętrznia się specyficzne podejście do tekstów i sposób ich postrzegania. Znaczenia nabiera indywidualność tekstu (niepowtarzalność i jedyność), wieloperspektywiczność (istnienie wielu perspektyw „przedstawienia”, struktur, elementów stylistycznych, norm tekstowych) i przede wszystkim jego nadsumatywność, na którą zwracali uwagę niemieccy hermeneuci, podkreślający, że tekst nie jest prostą sumą, lecz skomplikowaną relacją różnych elementów ${ }^{35}$. Świadomość istnienia w tekście

(Romantyka $i$ inne opowiadania), ale również fragmenty powieści Vincenta Šikuli pt. Wakacje ze stryjem Rafaelem (Prázdniny so strýcom Rafaelom, 1966) wydanej w Polsce w 1976 roku. Por. V. Šikula, 1976: Wakacje ze stryjem Rafaelem. Katowice, Wydawnictwo Śląsk.

32 O oficjalnej polityce przekładowej obowiązującej w drugiej połowie XX wieku do 1989 roku zob. W. Nawrocki, 1983: Czeska i słowacka literatura piękna w Polsce w latach 1945-1980. Dzieje recepcji. W: W. Nawrocki, T. Sierny: Czeska i słowacka literatura piękna w Polsce. Dzieje recepcji i bibliografia. Katowice, Wydawnictwo Śląsk, s. 7-70.

33 Por. V. Mikula, 2017: Socialistický realizmus v slovenskej poézii. Texty a interpretácie. Bratislava, Univerzita Komenského, s. 210—212, 217.

34 Jerzy Pleśniarowicz był autorem książkowego wyboru poezji Vojtecha Mihálika pt. Płomień i pocałunek. Por. V. Mihálik, 1978: Płomień i pocałunek. J. Pleśniarowicz, B.S. Kunda, wybór. B.S. Kunda, posłowie. Kraków, Wydawnictwo Literackie.

35 F. Paepcke, 2009: Rozumienie tekstu a przekład. W: P. Bukowski, M. Heydel, red.: Wspótczesne teorie przekładu. Antologia. Kraków, Wydawnictwo Znak, s. 338-339. 
sieci złożonych relacji, uzewnętrzniona w procesie przekładu, pozwala na wciągnięcie odbiorcy w proces przekazu, umożliwiając mu doświadczenie „pełni rzeczywistości tekstu"36 . Dla Jerzego Pleśniarowicza celem aktu translacji stawało się doświadczenie wyznawanej przez hermeneutów „prawdy tekstu” ${ }^{37}$, „prawdy przekładu" ${ }^{38}$ według Hansa-Georga Gadamera; doświadczenie określane przez Antoine’a Bermana „doświadczeniem obcego" ${ }^{39}$; uwrażliwienie odbiorcy sekundarnego na „istotowe jądro” w ujęciu Waltera Benjamina ${ }^{40}$; na ontologiczne uwarunkowania utworu, na sens (nie znaczenie poszczególnych słów) i formę. Doświadczenie to ustanawiał przez określenie stosunku tego, co swoje, do tego, co obce. W jego przekładach uzewnętrzniało się pragnienie odkrycia przede wszystkim obcości/inności, włączenie jej w nowy horyzont odbioru. Unikał w akcie translacji deformacji, które uniemożliwiały jej doznanie. Odrzucając racjonalizację, objaśnianie, wydłużanie, uszlachetnianie ${ }^{41}$, wystrzegał się ukonkretnienia, narzucenia przekładowi określoności, „rozjaśniającej jednoznaczności", na którą zwracał uwagę Gadamer ${ }^{42}$, niepotrzebnego rozwinięcia (eksplikacji) ukrytej wymowy znaczeń. Podobna strategia i cel translacji łączyły przekłady poezji współczesnej, między innymi Mašy Halamovej, Miroslava Válka, Jána Stachy czy Štefana Strážaya, i starszej, na przykład Pavla Országha Hviezdoslava. Przyglądając się uważnie wybranym translacjom utworów Mašy

36 Ibidem, s. 341-342.

$37 \mathrm{~W}$ ujęciu hermeneutycznym „prawda tekstu”, jako fenomen kognitywny uobecniająca się w świadomości tłumacza, oddawana jest przez niego odbiorcom nie drogą prostego transferu, ale re-ekspresji. Por. R. Stolze, 2009: Tłumaczenie jako proces ewolucyjny. W: P. Bukowski, M. Heydel, red.: Współczesne teorie przekładu. Antologia..., s. $349-355$.

38 Prawdą świadomości hermeneutycznej jest prawda przekładu - podkreślał H.-G. Gadamer. Jej wyższość „polega na tym, że daje ona możliwość przyswojenia czegoś obcego; prawdziwy przekład nie dokonuje bowiem tylko krytycznej destrukcji ani nie odtwarza czegoś bezkrytycznie, lecz interpretuje, posługując się własnymi pojęciami w swym własnym horyzoncie, wskazując na nowo znaczenie tego, co tłumaczy". H.-G. Gadamer, 2000: Semantyka i hermeneutyka. W: Idem: Rozum, słowo, dzieje. Szkice wybrane. K. Michalski, wybór, oprac., wstęp. M. Łukasiewicz, K. Michalski, tłum. Warszawa, Państwowy Instytut Wydawniczy, s. 130.

39 A. Berman, 2009: Przekład jako doświadczenie obcego. W: P. Bukowski, M. Heydel, red.: Współczesne teorie przekładu. Antologia..., s. 249-250.

40 W. Benjamin, 2012: Zadanie tłumacza. W: Idem: Konstelacje. Wybór tekstów. A. Lipszyc, A. Wołkowicz, tłum. A. Lipszyc, wstęp. Kraków, Wydawnictwo Uniwersytetu Jagiellońskiego, 2012, s. 29.

41 „Tendencje deformujące” przyjmuję za Antoine’em Bermanem. Por. A. Berman, 2009: Przekład jako doświadczenie obcego..., s. 251-264.

42 H.-G. Gadamer, 2009: Lektura jest przekładem. W: P. Bukowski, M. Heydel, red.: Współczesne teorie przekładu. Antologia..., s. 322. 
Halamovej, wyraźnie dostrzec można dążenie tłumacza do zachowania ukrytych sieci znaczeniowych oryginału:

Snívali sa mi ruky tvoje.

Jak slepec po písme

prstami hmatali mi po tvári

po nových vráskach neznámych.

Pri ústach zastali

v začudovanom geste.

Snívali sa mi ruky tvoje

dobré a bezpečné.

Ráno som mala

úsmev na tvári.

(M. Halamová: Snívali sa mi ruky tvoje ${ }^{43}$ )

Śniły mi się ręce twoje.

Jak ślepiec pisma niewidomych

palcami dotykały mojej twarzy,

nowych zmarszczek nieznanych.

Przy ustach przystanęly

w zdziwionym geście.

Śniły mi się ręce twoje

dobre i bezpieczne.

Dziś rano miałam

uśmiech na twarzy.

(M. Halamová: Śnity mi się ręce twoje, s. $323^{44}$ )

Tłumacz unika tu, podobnie jak w wielu swoich przekładach, nadmiernej retoryzacji i uszlachetnienia, zubożenia jakościowego (bogactwa dźwiękowego) czy ilościowego (straty leksykalnej). Jedyny wyjątek i odejście od obranej strategii stanowi w tym konkretnym przykładzie zastosowana w drugim wersie pierwszej strofy utworu amplifikacja: „Jak slepec po písme” — „Jak ślepiec pisma niewidomych". Jej cel nie wiąże się jednak z eksplikacją wyjaśniającą ukryte znaczenie, utrzymuje ona raczej porządek rytmiczny wersu, zespalając strofę w semantyczną całość.

43 M. Halamová, 1982: Smrt tvoju žijem. Bratislava, Slovenský spisovatel'.

44 Wszystkie cytaty polskich przekładów pochodzą z tomu: J. Pleśniarowicz, 2018: Wiersze i przekłady prozy... 
Zabiegi translacyjne Pleśniarowicza na ogół mieściły się w strategii translacji konsekwentnie odrzucającej interpretacyjny nadmiar i językowe przemieszczenie ${ }^{45}$. Szczególnie widoczne staje się to w tłumaczeniach oszczędnej w słowa, nasyconej pod względem semantycznym poezji Štefana Strážaya:

Pokojne dýcha lampa

a všetko si o tebe pamätá,

vyzliekaš si košelu:

tak budeš umierat.

Napadlo snehu až po ramená

nahých krížov.

Je noc, vyzliekanie a lampa

svieti už len do seba.

(S. Strážay: Úzkost' z vyzliekania ${ }^{46}$ )

Spokojnie oddycha lampa

i wszystko o tobie pamięta,

zdejmujesz z siebie koszulę:

tak będziesz umierać.

Napadało śniegu aż po ramiona

nagich krzyżów.

Jest noc, rozbieranie i lampa

świeci już tylko dla siebie.

(S. Strážay: Lęk z rozbierania, s. 444)

Tłumacz wykazuje istotną w tłumaczeniu poezji świadomość, że wzrost liczby jednostek werbalnych, pogłębienie gramatycznej złożoności, ujawnienie ambiwalencji i możliwych znaczeń wpływa na spójność i zrozumienie. Zachowuje $\mathrm{w}$ przekładzie pozostające $\mathrm{w}$ domyśle sensy oryginału, denotatywne, konotatywne, intencjonalne, asocjacyjne zakresy znaczeń, decydując się na dosłowność, na przekazujący posmak oryginału i jego sens przekład „słowo w słowo".

Wszelkie transformacje, sposób ekwiwalentyzacji, oszczędne stosowanie translatorycznych technik (amplifikacji, substytucji, redukcji, inwersji) służyć miało zazwyczaj przebiegowi rytmicznemu utworu, zachowaniu jego tkan-

45 O strategii interpretacyjnego nadmiaru por. G. Steiner, 1998: Akt hermeneutyczny. W: G. Steiner: Po wieży Babel. Problemy języka i przekładu. O. Kubińska, W. Kubiński, tłum. Kraków, Universitas, s. 446.

46 Dostępne w Internecie: https://www.babelmatrix.org/works/sk/Strážay\%2C_Šte fan-1940/Úzkost__z_vyzliekania/en [dostęp: 10.01.2020]. 
ki brzmieniowej, asocjacji. Widać to również w kolejnych przekładach wierszy Halamovej czy Stachy, w których tłumaczeniu podstawowa trudność polegała na oddaniu nierozerwalnej więzi znaczonego i znaczącego, sensu i brzmienia ${ }^{47}$.

Napísat' literami hviezd

len slovo v oblohy oko!

Napísat' mocne, vysoko,

aby ho nikto nemohol zniest'.

Aby večne bolo čisté,

nepadlo v priepasti blata -

napísat' literou zlata

v dialavy, výšky striebristé:

Milujem!

(M. Halamová: Láska ${ }^{48}$ )

Napisać literami gwiazd

słowo jedyne w niebios mrokach.

Napisać trwale i wysoko,

by nikt nie starł, nawet czas.

Ażeby wiecznie było czyste,

nigdy nie spadło w przepaść błota -

niech sieje blask litera złota

przez dale jasne, mgły srebrzyste:

Kocham!

(M. Halamová: Miłość, s. 322)

Mlčíme, žiari zlatá kôra chleba,

kým tichá mama poumýva riad.

Rozbila tanier. Mesiac zmizol z neba.

Ked'žmýka vechet', začína sa liat'.

Šuštanie namokajúceho piesku.

$\mathrm{Z}$ jačmeňa $\mathbf{v}$ okne jastrab vybuchol.

Nôž cengol z vody. V modrom svetle blesku

vzblikol nám v očiach vydrhnutý stôl.

$47 \mathrm{Na}$ te aspekty w przekładzie poezji zwracał uwagę hermeneuta Paul Ricoeur, podkreślając problematyczność przekładalności tego rodzaju literackiego. Por. P. Ricoeur, 2008: O tłumaczeniu..., s. 35, 59.

48 M. Halamová, 2001: Snívali sa mi ruky tvoje. Lúbostné verše slovenských poetiek. Bratislava, Slovenský spisovatel. 
Hrmí. Kôň dupe po pieskovej pláni.

A lampa dalej čierna zostala.

Žeravý uhlík na dedovej dlani

žmurká jak mačka, ked’ je ospalá.

(J. Stacho: V modrom svetle blesk $u^{49}$ )

Milczymy. Błyszczy złota kora chleba.

Matka naczynia teraz zmywa. Lecz

rozbiła talerz - księżyc zniknął z nieba.

Wykręca ścierkę - chlusnął nagły deszcz.

Chrzęst coraz gęstszy moknącego piasku.

$\mathrm{Z}$ jęczmienia wybuchł jastrząb, runął w dół.

Nóż brzęknął. W modrym błyskawicy blasku

cisnął płomienie naszym oczom stół.

Grzmi. Od pustkowia dudni tętent konia.

Lampa przykryta ciemnością bez gwiazd.

Tylko węgielek na dziadkowej dłoni

jak kocię senne mruga raz po raz.

(J. Stacho: W modrym blyskawicy blasku, s. 43)

Zastosowane w wierszu Halamovej substytucje („v oblohy oko” — „w niebios mrokach”; „napísat mocne” — „napisać trwale”), połączone z amplifikacjami („aby ho nikto nemohol zniest” — „by nikt nie starl, nawet czas”; „napísat' literou zlata” — „niech sieje blask litera złota”; „v dialavy, výšky striebristé” — „przez dale jasne, mgły srebrzyste") budują rytm wiersza, intensyfikują jego brzmienie i ekspresję wyrazu. Podobnie w wierszu Stachy, tu jednak, oprócz substytucji czy amplifikacji, tłumacz dla oddania znaczenia, brzmienia i ekspresji frazy zdecydował się na zastosowanie inwersji i redukcji („kým tichá mama poumýva riad” - „Matka naczynia teraz zmywa. Lecz”; „Ked žmýka vechet', začína sa liat” - „Wykręca ścierkę - chlusnął nagły deszcz”; „Z jačmeňa v okne jastrab vybuchol” - „Z jęczmienia wybuchł jastrząb, runął w dół”).

$\mathrm{Z}$ analogiczną strategią translacji mamy do czynienia w przekładach poezji starszej. Także tu dobór ekwiwalentu, transformacje (amplifikacje, substytucje), które stosował Pleśniarowicz, służyły oddaniu sensu, rytmu, brzmienia. W tym przypadku tłumacz nie unikał również archaizacji, zakorzenienia języka w uzusie, rytmie mowy z przeszłości, pomagając odbiorcom sekundar-

49 J. Stacho, 2001: Svadobná cesta. Bratislava, Vydavatel'stvo Spolku slovenských spisovatel'ov. Dostępne w Internecie: https://zlatyfond.sme.sk/dielo/489/Stacho_Svadobna -cesta/1\#ixzz6C2RvwiwB [dostęp: 10.01.2020]. 
nym umiejscowić obce dzieło w epoce, nurcie, narodowym repertuarze. Jego przekłady starszej poezji, odkrywające dystans między epokami historycznymi, uwrażliwiać miały świadomość dziejową odbiorcy. Wyraźnie uwidaczniają to tłumaczenia poezji słowackiego parnasisty i symbolisty Pavla Országha Hviezdoslava:

Trávička zelená už porástla briežkom:

a to moje srdce ešte vždy pod sniežkom, pod sniežkom, ej, sniežkom, ktorý padol vtedy, ked’ si bol, šuhajko, u nás naposledy. Ale cítim, cítim, že pomaly hynie len čo za slniečko tomu na príčine? či to nebom, či to ned’aleko v okne? lebo cítim, jak mi neraz líčko zmokne...

(P.O. Hviezdoslav: ${ }^{* *}[\text { Travička zelená... }]^{50}$ )

Murawa zielona wyziera już brzegiem, ale serce moje wciąż jeszcze pod śniegiem, pod śniegiem, ej śnieżkiem, co prószył w tę ciszę, kiedyś ty, mój miły, ostatni raz przyszedł. Jednak czuję, czuję, że zwolna topnieje jakież to słoneczko promieniami grzeje? $\mathrm{Na}$ wysokim niebie, czy w pobliskim oknie, bo czuję, że nieraz liczko mi zamoknie...

(P.O. Hviezdoslav: ${ }^{* * *}[$ Murawa zielona... $]$, s. 327)

Uzewnętrznienie w akcie translacji dystansu czasowego w postaci archaizacji językowej czy stylizacji historycznej, unaoczniające unikatowy charakter tekstu źródłowego, odsyłało do momentu powstania oryginału (w przypadku przytoczonego utworu do 1896 roku) i wiązało się z zachowaniem w przekładzie obcych konwencji, modeli wrażliwości, niestandardowych obszarów języka. Pleśniarowicz jako slawista, tłumacz z języków słowiańskich, nawiązywał w ten sposób do językowo-kulturowej świadomości odbiorców sekundarnych, zakładając rozpoznanie. Tłumacząc utwory z końca XIX i początku XX wieku (m.in. Janka Jesenskiego), opierał się na kryteriach porównania i analogii między literaturami bliskimi. Decydujące znaczenie miała dla niego jednak kwestia różnicy, której doświadczenie, jak podkreślał George Steiner, pozwala odbiorcom

50 P.O. Hviezdoslav: Letorosty III. Dostępne w Internecie: https://zlatyfond.sme. sk/dielo/202/Orszagh-Hviezdoslav_Letorosty-III/15\#ixzz69xzyyrvM [dostęp: 10.01.2020]. 
sekundarnym na doświadczenie własnej tożsamości, własnego języka, tradycji, kultury, zasobów wrażliwości i intelektu ${ }^{51}$.

We wszystkich przekładach polskiego tłumacza przejawia się zasada wyznawana przez hermeneutów, że przekłada się nie znaczenia słów, lecz myśl,

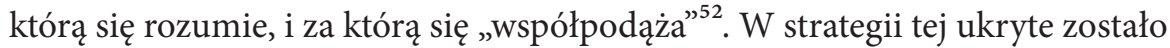
także pragnienie przekładu, na które zwracał uwagę Paul Ricoeur, nawiązując do Antoine’a Bermana twierdzącego, że wykracza ono „poza przymus i poza użyteczność" ${ }^{53}$. W swojej działalności przekładowej Jerzy Pleśniarowicz koncentrował się na akcie, który można, powołując się na teorię Steinera, określić jako akt hermeneutyczny. W akcie tym zrozumienie dzieła rozpoczyna się od aktu „zaufania” - ufności pokładanej w ,innym”, zwracającej uwagę na symboliczne bogactwo świata ukonstytuowanego w utworze oryginalnym. Następnie w akcie "agresji” tłumacz wkracza w tekst, wydzierając jego znaczenie, przenosząc je poza oryginał i włączając w nowe pole semantyczne (akt „ucieleśnienia”), aby ostatecznie uruchomić proces dowartościowania i wyniesienia utworu oryginalnego w nowym horyzoncie odbioru (akt „kompensacji”) ${ }^{54}$. Przekłady słowackiej literatury w tłumaczeniu Pleśniarowicza, biorąc pod uwagę historyczny punkt widzenia, kontekst kulturowy, kontekst odbioru, służyły obcemu i obcości czy też innemu/inności; podnosić miały status oryginału, ujawniać potencjał tekstu źródłowego, wydobywać jego pierwotne zasoby, a tym samym poszerzać horyzont odbioru czytelników sekundarnych, horyzont ich rodzimego języka, literatury i kultury. Znacząca dla polskiego tłumacza była świadomość odpowiedzialności za diachroniczne i synchroniczne przemieszczenie oraz zachowanie energii znaczenia tekstu, ściśle powiązane $\mathrm{z}$ intencją wprowadzenia obcego utworu w przestrzeń kultury sekundarnej, nawiązania dialogu, komunikacji i porozumienia między językami, literaturami, kulturami.

Odkrywanie obcości, docieranie do prawdy tekstu umożliwia tłumaczom wiedza w zakresie komparatystyki kulturowej, na płaszczyźnie ogólnej wiedza o tradycji, kulturze, literaturze itd. ${ }^{55}$, „ogrom teoretycznych, kulturowych i językowych założeń" - podkreślał Steiner ${ }^{56}$. Pleśniarowicz dysponował istotnymi dla aktu translacji kompetencjami, wyostrzoną świadomością literacką i kulturową, wpisaną w rozległe obszary słowiańskie i niesłowiańskie. W swych

51 Por. G. Steiner, 1998: Akt hermeneutyczny. W: Idem: Po wieży Babel..., s. 490.

52 F. Paepcke, 2009: Rozumienie tekstu a przekład..., s. 341.

53 P. Ricoeur, 2008: Paradygmat przekładu. W: P. Ricoeur: O tłumaczeniu..., s. 46.

54 Por. G. Steiner, 1998: Akt hermeneutyczny. W: Idem: Po wieży Babel..., s. 405-413.

55 Por. P. Bukowski, 2012: Dydaktyczne aspekty hermeneutycznej teorii przekładu. W: M. Piotrowska, J. Dybier-Gajer, red.: Przekład - teorie, terminy, terminologia. Kraków, Tertium, s. 22.

56 G. Steiner, 1998: Akt hermeneutyczny. W: Idem: Po wieży Babel..., s. 526. 
propozycjach przekładów częstokroć nie ułatwiał odbiorcy rozumienia sensów implikowanych, unikał prostych rozwiązań, interpretacji wyjaśniającej, skupiając się na interpretacji ukierunkowanej na zrozumienie obcego sensu. Istotnym celem stawało się wciągnięcie odbiorcy sekundarnego $\mathrm{w}$ proces rozumienia, we wspomniane „współpodążanie”, tj. „niepodzielne doświadczenie pełni” ${ }^{57}$. Posiadał ważne dla tłumacza predyspozycje natury psychologicznej: empatię, intuicję, wyczucie językowe, receptywność i kreatywność ${ }^{8}$. Empatia umiejętność wczucia się w dwa światy kulturowe, „konieczna podstawa kompetencji tłumacza" ${ }^{39}$; intuicja - ważny element ludzkiego poznania świata ${ }^{60}$, „żywa zdolność przeczuwania [...] imitatywno-wariacyjne obcowanie tłumacza z tekstem" ${ }^{61}$; wyczucie językowe - element ogólnej sprawności językowej, podstawa kreatywności i swobody formułowania obcego dyskursu i perspektywy językowej tekstu w języku docelowym ${ }^{62}$; receptywność - rozumienie tekstu, umiejętna jego lektura, umożliwiająca otwarcie się na jego sens i przekazanie jego „prawdy” czytelnikowi, także ważna zdolność gromadzenia indywidualnych doświadczeń, nabywanych poprzez lektury ${ }^{63}$, w końcu kreatywność - umożliwiająca powstanie przekładu eksperymentalnego, rozszerzającego obowiązujące normy językowe. Wszystkie te predyspozycje, w ujęciu hermeneutów konieczne do tłumaczenia literatury pięknej, Pleśniarowicz z powodzeniem wykorzystywał. Jego przekłady uwrażliwiały sekundarnych odbiorców na słowacką literaturę, wprowadzały ją w polski horyzont odbioru, odkrywając w kulturze docelowej jej indywidualność i swoistość.

Przekłady poezji słowackiej zamieszczone w tomie Wiersze i przekłady wierszy wydanym w 2018 roku przypominają i potwierdzają fenomen Jerzego Pleśniarowicza, ujawniając twórczą podmiotowość tłumacza, który dzięki swej wiedzy, świadomości kulturowej i translatorskim kompetencjom doprowadził do zaistnienia w polskim horyzoncie odbioru obcego/innego, poszerzając jednocześnie horyzonty konceptualne czytelników sekundarnych o nowe przestrzenie znaczeń. Wybór przekładów w jego translatorskiej interpretacji, zamieszczony w tomie, konstytuuje obraz rozwoju poezji słowackiej: od parnasistów i symbolistów, poprzez nadrealistów, poetów Mladej tvorby, do twórców

57 Por. F. Paepcke, 2009: Rozumienie tekstu a przekład..., s. 341-342.

58 Por. P. Bukowski, 2012: Dydaktyczne aspekty hermeneutycznej teorii przekładu..., s. 22-23; G. Steiner, 1998: Rozumienie jako przekład. W: Idem: Po wieży Babel..., s. 59.

59 R. Stolze, 2003: Hermeneutik und Translation. Tybinga, Gunter Narr, s. 123.

60 Por. ibidem, s. 109.

61 F. Paepcke, 2009: Rozumienie tekstu a przekład..., s. 346.

62 Por. R. Stolze, 2003: Hermeneutik..., s. 308; P. Bukowski, 2012: Dydaktyczne aspekty..., s. 22.

63 Ibidem. 
współczesności, wskazując jej wartość artystyczną, literacką, kulturową. Przypomniane współcześnie tłumaczenia pokonują czasowo-przestrzenny dystans, nadając poezji słowackiej nowy wymiar, podkreślając tkwiący w niej artystyczny potencjał, odkrywając w nowym kontekście odbiorczym nowe możliwości interpretacyjne. Można powiedzieć, że oryginał zyskuje w tym przypadku nie tylko na różnych typach relacji łączących go z przekładami, lecz także na dystansie dzielącym go od przekładów. Ujmując to słowami hermeneuty: poezji słowackiej poprzez wznowione przekłady nadaje się „nowe światło”, które na nowo ją oświetla, ujawniając niedostrzegane dotąd znaczenia i jakości ${ }^{64}$. Przekłady te wykazują postulowaną przez Paula Ricoeura "gościnnośc” ${ }^{65}$, zapraszając odbiorców sekundarnych, umiejscowionych we współczesnym horyzoncie odbioru, do otwartego dialogu, do obcowania z tekstami kultury, odszyfrowywania dziedzictwa przeszłości, które pomocne staje się w rozumieniu siebie, swojej kultury i tradycji.

\section{Literatura}

Benjamin W., 2012: Konstelacje. Wybór tekstów. A. Lipszyc, A. Wołkowicz, tłum. A. Lipszyc, wstęp. Kraków, Wydawnictwo Uniwersytetu Jagiellońskiego.

Berman A., 2009: Przekład jako doświadczenie obcego. W: P. Bukowski, M. Heydel, red.: Wspótczesne teorie przekładu. Antologia. Kraków, Wydawnictwo Znak, s. 249-250.

Bosak A., [online]: Rzeszowski teatr wspomina Jerzego Pleśniarowicza. Dostępne w Internecie: https://www.biznesistyl.pl/ludzie/sylwetki/5235_.html [dostęp: 5.01.2020].

Bukowski P., 2012: Dydaktyczne aspekty hermeneutycznej teorii przekładu. W: M. Piotrowska, J. Dybier-Gajer, red.: Przekład - teorie, terminy, terminologia. Kraków, Tertium.

Debkiewicz G., Wilk A., oprac., [online]: Spis zawartości czasopisma „Kamena” w latach 1945-1993. Dostępne w Internecie: http://biblioteka.teatrnn.pl/ dlibra/Content/26063/KAMENA_umcs_ost.pdf [dostęp: 10.12.2019].

Feldek L., 1962: Metaforou ku komplexnosti. „Kultúrny život”, č. 32.

Gadamer H.-G., 2000: Rozum, słowo, dzieje. Szkice wybrane. K. Michalski, wyb., oprac., wstęp. M. Łukasiewicz, K. Michalski, tłum. Warszawa, Państwowy Instytut Wydawniczy.

64 Por. G. Steiner, 1998: Po wieży Babel..., s. 411.

65 Por. P. Ricoeur, 2008: O ttumaczeniu..., s. 38. 
Gadamer H.-G., 2009: Lektura jest przekładem. W: P. Bukowski, M. Heydel, red.: Współczesne teorie przekładu. Antologia. Kraków, Wydawnictwo Znak, s. 322.

Hamada M., 1966: V hladaní významu a tvaru. Bratislava, Smena.

Heydel M., 2013: Gorliwość tłumacza. Przekład poetycki w twórczości Czesława Miłosza. Kraków, Wydawnictwo Uniwersytetu Jagiellońskiego.

Hochel I., 2007: Poézia. W: I. Hochel, L. Čúzy, Z. Kákošová: Slovenská literatúra po roku 1989. Bratislava, Literárne informačné centrum.

Jerzy Pleśniarowicz, hasło. Dostępne w Internecie: http://www.encyklopediatea tru.pl/autorzy/3850/jerzy-plesniarowicz [dostęp: 5.01.2020].

Jerzy Pleśniarowicz, hasło. Dostępne w Internecie: https://pl.wikipedia.org/wiki/ Jerzy_Ple\%C5\%9Bniarowicz [dostęp: 5.01.2020].

Krčméry Š., 1943: Stopätdesiat rokov slovenskej literatúry. Martin, Matica slovenská.

Mikula V., 1987: Hladanie systému obraznosti. Bratislava, Smena.

Mikula V., 2005: Strážay Štefan. W: V. Mikula, ed.: Slovník slovenských spisovatelov. Bratislava, Kalligram, Ústav slovenskej literatúry SAV, s. 514-515.

Mikula V., 2017: Socialistický realizmus v slovenskej poézii. Texty a interpretácie. Bratislava, Univerzita Komenského.

Nawrocki W., 1983: Czeska i słowacka literatura piękna w Polsce w latach 19451980. Dzieje recepcji. W: W. Nawrocki, T. Sierny: Czeska i słowacka literatura piękna w Polsce. Dzieje recepcji i bibliografia. Katowice, Wydawnictwo Śląsk, s. 7-70.

Paepcke F., 2009: Rozumienie tekstu a przekład. W: P. Bukowski, M. Heydel, red.: Współczesne teorie przekładu. Antologia. Kraków, Wydawnictwo Znak, s. $338-339$.

Pleśniarowicz K., 1993: Jerzego Pleśniarowicza ślad pozostawiony. K. Pleśniarowicz, wybór i oprac. Kraków, Szkice.

Pleśniarowicz J., 2018: Wiersze i przekłady wierszy. K. Pleśniarowicz, J. Pleśniarowicz, red. i oprac. Kraków, Bricolage Publishing.

Pleśniarowicz J., 2019: Przekłady prozy. K. Pleśniarowicz, J. Pleśniarowicz, red. Kraków, Bricolage Publishing.

Pound E., 1968: Literary Essays of Ezra Pound. New York, New Directions.

Pym A., 1998: Method of Translation History. Manchester, St. Jerome Publishing.

Rédey Z., 2017: Od „poézie vecí” k „poetike vecnosti” (Lyrika Štefana Strážaya). Levoča, Modrý Peter.

Ricoeur P., 2008: O tłumaczeniu. T. Swoboda, S. Ulaszek, tłum. E. Balcerzan, wstęp. Gdańsk, Wydawnictwo Uniwersytetu Gdańskiego.

Sedlák I., Čúzy L., 2009: Dejiny slovenskej literatúry II. Bratislava, Martin, Literárne informačné centrum, Matica slovenská. 
Spuścizna translatorska Jerzego Pleśniarowicza: poezja słowacka, 1985. „Kamena”, nr 4 (824).

Spyrka L., 2016a: Dramat słowacki w Polsce. Przekład $w$ dialogu kultur bliskich. Katowice, Wydawnictwo Uniwersytetu Śląskiego.

Spyrka L., 2016b: Koncepcja przekładu L’ubomíra Feldka $w$ kontekście słowackiej myśli przekładoznawczej. „Przekłady Literatur Słowiańskich”, t. 7, cz. 1, s. 64-77.

Steiner G.: Po wieży Babel. Problemy języka i przekładu. O. Kubińska, W. Kubiński, tłum. Kraków, Universitas.

Stolze R., 2003: Hermeneutik und Translation. Tybinga, Gunter Narr.

Stolze R., 2009: Tłumaczenie jako proces ewolucyjny. W: P. Bukowski, M. Heydel, red.: Współczesne teorie przekładu. Antologia. Kraków, Wydawnictwo Znak, s. 349-355.

\section{Marta Buczek Jerzého Pleśniarowicza dôkaz v prekladoch}

RESUMÉ | Príspevok sa zameriava na osobnost' Jerzého Pleśniarowicza, známeho pol’ského básnika zo skupiny poetov súvisiacich s poéziou Józefa Czechowicza, divadelného režiséra, ktorý priniesol na polskú divadelnú scénu drámy slovenských dramatikov (Júliusa Barča-Ivana, Ivana Bukovčana, Lubomíra Feldeka, Osvalda Zahradníka) a najmä prekladatela slovanských literatúr. Autorku článku zaujíma fenomén Pleśniarowicza ako prekladatela slovenskej literatúry. V stati sa podrobne analyzujú jeho polské preklady slovenskej poézie, predstavené v zborníku Wiersze i przekłady wierszy, ktoré boli uverejnené v Polsku v roku 2018. Štúdia zohladňuje výber prekladov, ktoré sú silnou deklaráciou prekladových a poetických názorov Pleśniarowicza, okrem iného preklady predstavitelov surrealistickej skupiny poézie (Rudolfa Fábryho, Vladimíra Reisela, Pavla Bunčáka, Júliusa Lenka, Štefana Žáryho), básnikov z Trnavskej skupiny (Lubomíra Feldeka, Jána Ondruša, Jána Stacha), predstavitelov skupiny Mladá tvorba a súčasných básnikov (Milana Rúfusa, Miroslava Válka, Jána Buzássyho, Vlastimila Kovalčíka, Vojtecha Kondróta, Štefana Strážaya či Vojtecha Mihálika). Príspevok tiež reflektuje interpretáciu prekladatelských stratégií Pleśniarowicza, úzko spojenú s jeho poetikou, a tiež zahŕňa diskusiu o súčasnom význame prekladanej poézie v pol’skom horizonte prijatia.

KLÚČOVÉ SLOVÁ | slovenská poézia v Polsku, polské preklady slovenskej poézie, recepcia prekladov slovenskej literatúry, slovenská poézia v polskej recepcii, Jerzy Pleśniarowicz 


\section{Marta Buczek \\ Jerzy Pleśniarowicz's Trace Left in Translations}

SUMMARY | This article focuses on the career of Jerzy Pleśniarowicz, the well-known Polish translator of Slavic literatures and poet associated with the Józef Czechowicz poetry group, and who, in his capacity as dramatist and theatre director, has directed on the Polish scene plays by Slovak dramatists including Július Barč-Ivan, Ivan Bukovčan, Lubomír Feldek, Osvald Zahradník. The article discusses the output of this poet, viewing him primarily as a translator of Slovak literature; it goes on to analyse his Polish translations of Slovak poetry published in the 2018 volume Wiersze i przekłady wierszy (Poems and Translated Poems). The anthology focuses on the representatives of three main groups: the surrealist poetry group consisting of, among others, Rudolf Fabry, Vladimír Reisel, Pavol Bunčák, Július Lenko, and Štefan Žáry; the Trnavská skupina poetry group, including Lubomír Feldek, Ján Ondruš, and Ján Stacho; and finally the Mladá tvorba group with the contemporary poets Milan Rúfus, Miroslav Válek, Ján Buzássy, Vlastimil Kovalčík, Vojtech Kondrót, Štefan Strážay, and Vojtech Michálik. The author considers Pleśniarowicz's translation choices, which are also a strong declaration of his views. She elucidates his translation strategies, pointing out close ties with the poetics of his own work, and also discusses the contemporary significance of this poetry in the Polish sphere of reception.

KEYWORDS | Slovak poetry in Poland, Polish translations of Slovak poetry, reception of translations, Polish reception of Slovak poetry, Jerzy Pleśniarowicz, translator's visibility

MARTA BUCZEK | dr, adiunkt na Wydziale Humanistycznym Uniwersytetu Śląskiego w Katowicach; literaturoznawczyni, słowacystka. Prowadzi badania z zakresu translacji w obrębie literatur zachodniosłowiańskich w perspektywie teoretycznej, historycznoliterackiej i historycznokulturowej. Jej zainteresowania naukowe koncentrują się wokół przekładu i recepcji literatury słowackiej w Polsce ze szczególnym uwzględnieniem literatury XX wieku oraz literatury najnowszej. Autorka książki O polskich przekładach prozy Vincenta Šikuli (2010) i ponad dwudziestu artykułów naukowych dotyczących badań nad przekładem, recepcji literatury polskiej w Słowacji i słowackiej w Polsce, kulturowych uwarunkowań przekładu, specyfiki przekładu w granicach języków bliskopokrewnych, roli przekładu w badaniach komparatystycznych. 
